\title{
Redefining The Term of Dukun
}

\author{
Sartini, Heddy Shri Ahimsa-Putra \\ Universitas Gadjah Mada \\ Email: tinisartini2013@gmail.com
}

\begin{abstract}
Dukun, wong pinter, and other terms, commonly constitutes to the term of shamanism, are often interpreted in the same way. In particular, the dukun and wong pinter are generally understood as persons who have extraordinary or even supernatural powers, are capable of communicating with spirits and understanding the unseen, can generally help resolve issues faced by members of their communities, including illnesses, spiritual disturbances, lost items, unfortunate fates, etc. They are also predicated to charge to the patient and even willing to help witchcraft to harm other people. In fact, not all shamans have negative behaviors. In Temanggung, Central Java, though this general understanding is still common, there is distinction in the specific details and characteristics of the dukun and wong pinter. Dukun are often understood negatively, meanwhile the wong pinter has more positive connotations. Because of the different principle meaning the both terms should not be generalized and used appropriately and wisely. Improper use can cause discomfort in the community, and academically the both term actually refers to a completely different subject characteristics.
\end{abstract}

Keywords: behavior, dukun, negative, positive, redifining, term

\section{INTRODUCTION}

Though developments in medicine have advanced modern treatments greatly, traditional healing still plays an important role in society. That it is common to see banners and advertisements offering alternative healing treatments or products, such as herbal medicines, indicates that belief in traditional healing has, rather than being eliminated by the advent of modern medical technology, remained strong in society. Traditional treatment methods have been practiced and developed throughout human history. Among the various traditional healing practices are those practiced by shamans, a phenomenon which has widely been studied by researchers.

On the international scale, the writings of Eliade (Eliade, 1989), (Harvey, Wallis, \& Harvey, 2010) Atkinson (Atkinson, 1992), Pearson (Pearson, 2002), Lebra (Lebra, 1985), Jordan
(Jordan, n.d.) Winkelman (Winkelman, 2010) Jacobsen, (Maddox, 2003), Edson (Edson, 2012), (Chilson \& Knecht, 2003), and (Heinze \& Berney, 1991), show the wide spectrum of traditional healing methods categorized as shamanism. In Indonesia, research into shamanism has likewise been common. These include, for example, Lemelson, who investigated balian traditional healers of Bali (Lemelson, 2004, p. 57); Foley, who investigated the paraji of West Java (Foley, 1984, p. 54); Viner and Kaplan, who investigated the guru of the Pakpak Batak (Viner \& Kaplan, 1981, p. 98); Bernstein, who investigated the balien in Kalimantan (Bernstein, 1993, p. 1); Trisakti who investigated the balin of the Dayak (Trisakti, 2009); and Matondang, who investigated the balian of the Dayak Paser (Matondang, 2014). The practice of shamanism in Java has attracted numerous researchers, including Geertz (Geertz, 
1976), Mulder (Mulder, 2005a), Daniels (Daniels, 2009a), Sofwan (Sofwan, 2010) Woodward (Woodward, 2011), Hesselink (Monnais \& Cook, 2012a), Indrasuari (Indrasuari, 2012) and Sutiono (Sutiono, 2014).

In Central Java, there are the wong pinter (literally "clever people"), alternative treatment providers who are alternatively known as dukun ("shamans"), tabib ("medicine men"), ahli kebatinan ("mystic experts"), ahli thariqah ("experts in "the way"'), and ustadz or kyai (both terms for Islamic scholars) (Sofwan, 2010, pp. 1-2). These wong pinter are often considered equivalent to the practitioners named dukun in various references. Aside from dukun and wong pinter, there is also the term paranormal (i.e. persons with paranormal powers). The term dukun is generally used in rural areas, whereas the term paranormal is more common among urban populations (Schlehe, Nertz, \& Yulianto, 2013, p. 8).

Traditional healers are considered to be knowledgeable of health and disease, and are believed to have the ability to massage patients, to determine good days (for marriage, etc.), and to conduct circumcisions (Hesselink, 2011, pp. 1314). Other abilities include giving advice, giving directions, and giving spiritual guidance, as well as having considerable knowledge of mysticism. Owing to these abilities, among the Javanese these healers are frequently known as wong pinter. People go there for many purposes.

Generally, people go to the dukun or wong pinter when they feel ill (physically or nonphysically), or are facing uncertainty regarding their own fates, the election of officials, etc. The medical knowledge and treatments obtained from the dukun are unique, and their very presence brings their own (sometimes controversial) dynamics. Dukun are often said to be involved in incidents of violence, both as victims and as perpetrators. In the Banyuwangi region in 1998 , for instance, a number of suspected dukun santet ("sorcerers") were killed in acts which Siegel (Siegel, 2001) connects to the political intrigues of the Suharto-era government and which Herriman finds rooted in society's anxiety over rumors of "ninjas" (Herriman, 2010) and the murders of guru ngaji (prayer teachers) and kyai (Herriman, 2006).
The dukun or wong pinter and others in similar professions have a significant role in society. However, their presence has often been controversial. Several factors contribute to this negative view of dukun or wong pinter, who are often targets for their communities' anger and hatred, as in Banyuwangi. Do dukun and wong pinter automatically share the same characteristics, thus meaning that the same mistakes are made by all of them?

Observation conducted in Temanggung, Central Java, in 2014 has found that there is a clear distinction between the terms dukun and wong pinter. The wong pinter are often considered a special class of dukun, and though these terms are often equated when referring to Javanese shamans, the term wong pinter has its own special characteristics.

This article explains the existing understanding of the term dukun as "general magical specialists" or "magico-religious specialists" in general sense, the understanding of wong pinter as a special class of $d u k u n$, and propose the attitude to use the term. This article emphasize that there are different understandings on the term of "dukun". It means that the term should be used properly.

\section{FINDINGS AND DISCUSSION Dukun and Wong Pinter as General Terms}

Dukun has become a common term in Indonesia to refer to the practitioners of traditional medicine. Geertz and Khiun, for instance, use the term dukun, and both Geertz (Geertz, 1976, pp. 86-87) and Khiun (Khiun, 2012, p. 25 ) identify numerous categories of dukun, including dukun bayi (midwife shamans), dukun calak (circumcisers), dukun temanten (marriage specialists), dukun petungan (numerologists), dukun sihir (sorcerers), and, the most important of these according to Geertz is dukun biyasa, who are considered "general magical specialists" with a wide range of powers, including the ability to discover lost items, predict the future, and practice santet (witchcraft). Meanwhile, Sutiono (Sutiono, 2014, p. 1) uses the term wong pinter for shamans as they are generally found in Java. He refers to them as "magico-religious specialists", a definition relatively similar to that used by Geertz for the 
dukun biyasa or those used by other researchers for the term dukun. No research differentiating the dukun and wong pinter has been found to date.

The abilities and roles of traditional healers in Java, be they known as dukun, kyai, wong tuwa, wong pinter, etc., have been widely explored both through scientific research and through literature. One work by Katrin Bandel (Bandel, 2006, pp. 16-18) compares the image of traditional medicine (i.e. the image of the dukun) with the image of biomedical treatment (i.e. the image of doctors) in literature. The famous Babad Tanah Jawi ("History of the Land of Java") (Olthof, 2014, p. 3 ), which was written during the Mataram dynasty and transcribed by Olthof in 1941, contains an interesting story regarding the role of the dukun. In this story, a tenung (sorcerer) is sent by the Dutch East India Company in a secret attempt to kill the King for breaking his vow to the Company (Olthof, 2014, p. 324). Mystic abilities, thus, have long been known among the Javanese people. Indeed, several other works of classical Javanese literature deal with Javanese mysticism and magic, telling of ways to ensure one's safety, to calculate good days for specific activities, to live in peace with other people and nature, to find missing people, to cure diseases, etc. Such almanacs, or primbon, generally conveyed medicinal concepts and information regarding traditional medicines (Sudardi, 2002, p. 12). They were generally owned by elders, community leaders, dukun, and guru kebatinan, all of whom were considered the intellectuals of their times (Sudardi, 2002, p. 13). Such books can still be found, and the knowledge they contain remains part of the way of life of many Javanese communities.

\section{Existing Understanding of the dukun Knowledge, abilities, and powers of dukun}

Traditional healing practices are as widely dispersed as humankind itself. Anthropological research has frequently explored the roles of traditional practitioners. For instance, Taussig researched the shamans in the hills of Putumayo, Columbia, who are involved in healing, fortunetelling, and practicing magic (Taussig, 1987, pp. 139-170). Other research showed that the dukun in Bogang, Negeri Sembilan, Malaysia, use their shamanic powers to (for instance) treat poisoning, counter witchcraft, or provide pengasihan (love magic). These dukun also recognize numerous types of spirits (Peletz, 1988). There is a similarity in the provision of symbolic healing and use of spiritual forces by the shamans in Bali, Indonesia, and in Ontong Java (Connor, 1990), an atoll near the Solomon Islands (http://sb.geoview.info/ otong_java,8260752). Research into the Meratus tribe of Dayaks has also found shamanism, including enchantments (ilmu hirang) which can attack those lacking protection through a process of "poisoning by supernatural media". Owing to perceptions of the seriousness and threat of this practice, outsiders often consider entering Dayak areas to be difficult, and marrying into a Dayak family is likewise held to bring its own risks. Many believe that men who marry Dayak women must be careful, for if they plans to leave their wives, their genitals will either disappear or become detached (Grim, 1987, pp. 262-263). In such cases, dukun involvement is frequently cited.

Investigating the Dayaks in Kalimantan, it is found that the existence of dukun is heavily interlinked with knowledge of medicinal herbs (Caniago \& Siebert, 1998). Bernstein also writes of the dukun's prowess in providing traditional healing for diseases caused by one's body being entered by a spirit (Bernstein, 1993). Spirit ownership is a specialty of the dukun (Faucher, 2002). They may, as in West Java, be considered capable of handling mental conditions which are incurable through modern medical practice (Horikoshi-Roe, 1979), or of controlling spectral tigers as in Aceh (Ali, 1995). The dukun treat both physical and spiritual diseases, and may massage patients or give them herbal medicines (Gaines, 2002). They are also involved in maintaining celebrities' physical appearance (Suanda, 1981, p. 29) and in matchmaking (Singarimbun \& Manning, 1974, p. 77). Among the Batak, knowledge of the calendar system (ari-ari sitelupuluh) is critical for traditional practitioners, who are known as guru or dukun. They, as with other dukun in the villages of Indonesia and Malaysia, determine which dates are good for certain activities (Viner \& Kaplan, 1981, p. 98). More generally, dukun are connected to religious rituals, enchantments, or magic, or the control of spirits as in Bali (Lemelson, 2004, 
p. 57). In West Java, the healing role of the dukun is also taken by the dalang ("puppeteers") during wayang ("puppet") performances. The dalang heal by giving patients prayer water (Foley, 1984, p. 54). Healers' roles continue to grow, and traditional healing has even been used to treat drug addicts through meditation, faith healing, and acupuncture (Heggemhougen, n.d.).

According to Geertz (Geertz, 1976, pp. 90-91), there is a tendency of dukun to become involved in magic or sorcery and to charge for their services, even demand payment, contributes to society's ambiguous views of them, he notices a negative view of the dukun. As the services provided by the dukun are often considered objectionable, and as the dukun frequently ask their patients for money, they are viewed negatively and with much suspicion. As such, many dukun prefer to use the term pitulung ("helper"), which implies that they care only about helping others. This is supported by observations conducted in Temanggung.

In this research, the term dukun often carries negative connotations, such as an expectation of payment, a desire to help for personal profit, a willingness to do immoral acts, a desire to show off one's abilities, a lack of humility, a lack of interaction and integration with the community, and even a lack of willingness to provide advice to patients and neighbors (Sartini, 2014, p. 29).

Social view

Specifically, the term dukun is used as a label for traditional healers who have the following characteristics: having extraordinary powers; willing to give help, but not freely; and expecting remuneration or payment, or even posting fixed fees. These people tend to make use of their communities abilities and beliefs (Sartini, 2014, p. 23). This definition will be further explored with data regarding social views of the dukun, which will begin with a general description of the services they provide.

Research (Sartini, 2014, p. 23) indicates that the term dukun tends to refer to persons with extraordinary abilities who are willing to help, but expect remuneration/payment or even post fixed fees. Some community members refer to this expected payment as bebungah (gift) or mahar (dowry). If the dukun are not given any payment, they will generally still help their patients, but while nggrundel, muttering and without truly accepting this lack of payment. One source even said that the wong pinter (here used generically) who are better categorized as dukun, aside from expecting payment, will also akal ukil - use various tricks to take profits or other benefits from others. In other words, these dukun are held to frequently use their special abilities or, perhaps, the beliefs of their communities for their own specific purposes. This informant held that, if the aid given was successful, it was mostly because of suggestion, rather than the abilities of the "helper".

The term dukun tends to carry with it the connotations of a desire for profit and a willingness to manipulate social beliefs and abilities. To avoid these negative connotations, the dukun tend to prefer the terms pitulung (helper) or tiyang sepuh (elder) (Geertz, 1976, p. 96), or to be called an orang pinter or paranormal. They also attempt to exhibit religious (Islamic) beliefs and positive attitudes (Daniels, 2009a, p. 78).

The emergence of social problems or interpersonal/interfamilial intrigue, as a result (for instance) of conflict over land or power, can lead to a desire to use spells or enchantments. Doing so requires the involvement of a dukun (Retsikas, 2002). As illustrated by numerous anthropologists, the Javanese people have traditionally used the terms guna-guna and magic to refer to the spells of the dukun (Wiener, 2007, p. 501). Woodward argues that the term dukun is ambiguous, or even negative, in its connotations. It tends to imply specific economic and social realities, as well as the control and use of dangerous powers (Woodward, 2011, pp. 70-71). Woodward explores the Javanese dukun in his book through one chapter, which is given the title The Javanese Dukun: Healing and Moral Ambiguity. The focus of his research is the religious and cultural bases of traditional Javanese medicine. Woodward disagrees with Geertz' analysis, which argues that Javanese concepts of healing are based on tenets of an animistic Javanese religion. Rather, for Woodward, the understanding of health, disease, and healing in Java is based on an Islamic world view and Islamic theories of personhood. The absorption of Islamic theology, doctrine, and mysticism in Javanese healing traditions indicates a medical system, medical 
knowledge, and traditional practice which originate from outside Javanese culture. In his opinion, many of the abstract concepts of personhood, cosmology, power, and knowledge which shape the Javanese medical system can be traced to the Qur' an and the Middle East (Woodward, 2011, p. 69). Nevertheless, the Javanese dukun in Java frequently cause differences of opinion among society, particularly in relation to their spiritual powers. Much of society claims that these powers can only originate from turning against God and worshiping another deity (in Islamic doctrine, shirk) (Woodward, 2011, p. 83).

\section{Changing Profiles: Relationship with religion}

In the context of the relation between the dukun and their patients, the dukun are commonly referred to as tiyang sepuh, a form of respect similar to that of a child for his or her parent (Geertz, 1976, p. 96). Geertz sees that the term dukun as generally used contains within it a paradoxical ability to give assistance, which leads to suspicion and rejection of the dukun in society. This paradox comes from the fact that the dukun are often mentioned in connection with various incidents, either as victims or as perpetrators. The bloody killings which afflicted the Banyuwangi area around 1998 drew widespread attention from the general society and academics. Research conducted by Siegel (Siegel, 2001) regarding the political intrigues of Soeharto-era Indonesia, as well as by Herriman regarding rumors of "ninjas" (Herriman, 2010) and the killings of guru ngaji and kyai suspected of being dukun santét (Herriman, 2006) have shown this. The dukun have a powerful presence in politics, as found by Bubandt (Bubandt, 2006) in his examination of the correlation between sorcery and corruption in the derailing of democracy building in Indonesia. Witchcraft, or santet, as part of magical activities are an extension of politics, and in the political imagination of some people santet/witcheraft and corruption are linked. This contributes to an ambivalence in power transference issues. Strangely, dukun involvement is also apparent in the politics of power at universities, which represent the highest institutions of learning in Indonesia. During the transfer of power between officials at one university in East Java, several officials felt it necessary to protect themselves from the influence of santet or witchcraft. Thus, a dukun or kyai gave them a pagar pengasihan ("fence of grace") to be used to maintain their offices and to gather public support (Wessing, 1996).

Another development in the positioning of the dukun is the identification of these healers as paranormal, as practitioners of alternative medicine who base their treatments in Western rationalism. Traditional healing models have likewise begun to be modernized by increasing their levels of functional rationality, following developments in biomedicine, and transforming themselves in the face of global contexts and the Indonesian populace's increasingly sophisticated understanding of Islam (Woodward, 2011, p. 111). These dukun-doctors include dzikir (recitations), sholawat (supplication), and prayers (Daniels, 2009a, p. 71) in their treatments, thus modifying both rational Western treatments and Islamic spirituality. For Landy, such developments, which have occurred as an effect of acculturation, allow for a re-synthesis process which redirects individual rituals to new functions. Even treatments which are indigenous in character can complement scientific healing systems (Landy, 1974, p. 117).

Such healers have become common in society and refer to their work as alternative medicine. They utilize a variety of approaches, including jampi-jampi (incantations) and mantras, jamu (herbal medicine) made from plant material, nerve massages, prana ("cosmic energy") treatment, etc. These approaches are paired with prayer, dzikir, night time supplications, and meditation. Of all the terms used to refer to the them, the practitioners of these alternative treatments, whom Sofwan (2010, pp. 8, 78) names the wong pinter, prefer to be known as kyai, ustadz or tabib rather than dukun. Recently, there has been a tendency for practitioners of alternative medicine to promote themselves through such media as billboards, radio, and television.

Recent developments in Islam in Java have influenced how Muslims view alternative treatment methods. One view is that the healing abilities of a kyai are a realization of the powers granted to some Muslims through karomah (God's blessing). Others hold that these healers' spiritual powers are a form of direct communication with God. This 
can be connected to Sufism, which is part of the religious understanding being developed, together with worship based in the five pillars of Islam. Sufis put greater emphasis on the spiritual aspects of religion than rituals or outward adorations. Another view argues that these healers practice a syncretic form of Javanese animist religion and Islam, and thus theirs is not a truly Muslim faith (Woodward, 2011, pp. 94-97).

As part of their passion for returning to a more Muslim Islam, a number of healers have developed a prophetic way of healing and claimed it to be an Islamic treatment method. This method emphasizes dzikir, sholawat and prayers, as well as reading verses of the Qur'an, using prayer water, and applying physical therapies such as massage and herbal potions (Daniels, 2009a, pp. 77-79). The tendency for treatment to become more religion-based has been seen, for instance, in the preference of sellers at the Demak Market in choosing a dukun. These vendors tend to choose kyai as "prayer helpers", because the kyai are believed to have a better command of Islamic teachings than the dukun (Indrasuari, 2012, p. 1).

Daniels categorizes the traditional healers of Java into three ideal types, namely the dukun, kyai and ustadz. This categorization scheme is different than that of abangan, santri and priyayi formulated by Geertz, though both are used to understand plurality and local understandings of it. These categories are stated to be integral and fluctuative within the dynamics of society and cultural processes (Daniels, 2009a, p. 55). From this, it is clear that Daniels' categorization is also dynamic, and that his categories can mix, similar to Geertz' view that the categories of santri, priyayi, and abangan can be blurred (Geertz, 1976, p. 87). According to Daniels (Daniels, 2009a, p. 56), these three types of healers can be grouped into one of two main orientations based on their views: normative Sufi- and normative Salafi-oriented forms of healing, and un-Islamic forms of healings. Though Islam-oriented forms of healing are divided into two subcategories, both are united in their criticism of healing methods that they claim to be un-Muslim and thus inappropriate for treatment. Nevertheless, healers who reject local wisdombased healing (i.e. healing based in Kejawen, or syncretic Javanese religion) are unable to agree on which form of treatment is most properly named Islamic-based healing. The blurring of these categories has been seen as practices have developed. For instance, several healers who were originally not oriented towards Islam, who made use of magic and sorcery in their treatments, have reoriented themselves to be more Muslim.

In his research, Daniels has explored these dynamics and found that healing orientation has changed to be better suited to recent developments in religious understanding. However, the continued existence of these healers has continued to cause controversy over their claims of veracity, particularly as related to the religious values underlying their practices (Daniels, 2009b, pp. 78-79).

The terms dukun and wong pinter are often equated. They are both frequently used as general terms to refer to a person with special powers (including a connection with the spirit realm) who gives aid upon request. However, these terms can be differentiated between "white" and "black" practices, as well as internal and external ones, which have positive and negative connotations. The term wong pinter is more generally used to refer to persons with special powers, but has positive connotations (Sartini, 2014, p. 44).

\section{Characteristic of Wong Pinter as a kind of Dukun Special understanding}

Above, it has been mentioned that the term wong pinter is frequently understood as a general one, equivalent to the term dukun. If this were true, however, the ambiguous and negative characteristics connoted by the term dukun would also be conveyed by the term wong pinter. Though practitioners' efforts to obtain knowledge and abilities are similar, the term wong pinter indicates characteristics that are unlike those connoted by dukun or kyai. At least, this is what can be seen among the people of Temanggung, Central Java. Research has indicated the following information.

The term wong pinter, narrowly defined, refers to someone with special abilities, particularly those related to their ability to directly communicate with the supernatural but also including the ability to treat, to pray for, and to advise patients. It 
also connotes a helpful person who demands no recompense and high moral integrity (Sartini, 2015, p. 284). What are the differences of wong pinter and other names especially dukun and kyai?

Wong pinter, dukun and kyai have different meanings, though their characteristics are interrelated. Wong pinter is frequently asserted to be the same as dukun because both types of practitioners often provide aid. However, they differ significantly when it comes to the issue of remuneration. The wong pinter do not ask for any payment for their assistance, whereas the dukun generally demand material recompense. Wong pinter, meanwhile, has similarities to the term kyai as both terms refer to persons who provide aid or assistance, but differ significantly in the matter of knowledge of Islam. The wong pinter who are also kyai have a solid understanding of Islam. However, wong pinter need not always have a good command of Islamic doctrine, and some are not even practicing Muslims (Sartini, 2015, p. 284).

The wong pinter may inherit their knowledge, or obtain it by completing laku prihatin ("spiritual acts") such as observing special fasts (Sartini, 2014, p. 661) or conducting specific rituals and meditation. Their approach to providing treatment is more or less the same as that used by the dukun. The key point here is that the term wong pinter has positive connotations, rather than the negative ones associated with the term dukun (such as practicing sorcery or demanding recompense for their assistance). The wong pinter are considered to follow the demands of their religions and have uncompromised morals (Sartini, 2014, p. 661). These characteristics are similar to those which Mulder associates with the guru mistik ("mystic teachers").

In his exploration of Javanese mysticism, Mulder finds that traditional healing and social service activities are generally practiced by mystics known as guru mistik. This term, however, tends to have positive connotations in society (Mulder, 2005b). Mulder differentiates between the guru mistik and dukun. In his view, the dukun and other practitioners of Javanese esoterism are firmly differentiated from the guru mistik, despite having similar abilities and providing social aid, because of their characteristics. Although he does not provide an explicit description of characteristics associated with the dukun, he asserts that guru mistik are more frequently viewed as sepuh or wong tuwa, as exalted and honored elders whose wisdom is derived from the grace of God and is used for charity. They are of a special character, and are held to emanate mystery and knowledge. They live their lives responsibly, are prepared to bear worldly burdens, and have peace of soul. Many people depend on them, because they are thought to be blessed with clairvoyance and thus able to give accurate advice. The guru mistik are ideal father figures. The guru mistik are also believed to have the ability to treat diseases, calculate good dates, tell fortunes, and serve as mediators between the common people and spirits, ancestors, and God. Differing significantly from dukun traits as identified by Geertz, the guru mistik do not demand recompense for their assistance (Mulder, 2005b, p. 76). They tend to openly show their confidence as people who have strong ties to the highest reality, and are certain that theirs is a mission unlike that of the common people (Mulder, 2005b, p. 77).

\section{Services provided}

The services provided by wong pinter vary greatly. They may include physical healing, as well as treatment of diseases or other disturbances caused by spirits, fate-reading, etc. Research (Sartini, 2014, pp. 36-38) indicates three categories of aid often provided by the wong pinter such as: disease treatment, treatment of disturbances by spirits and finding of lost items, determination of good dates, and life aids such as: fortune, future, business.

Wong pinter often treat persons with various physical illnesses, such as stomach pain, diabetes, tumors, and cancer. Patients seek out the wong pinter for to save both money and time. Seeing a wong pinter does not require any administrative hassle, nor does it require payment. Likewise, patients who have already undergone extensive medical treatment at hospitals without success will use the wong pinter as an alternative form of treatment. Some of the persons who seek aid are poor and uneducated. For instance, one patient experienced continuing stomach pain despite having seen a doctor numerous times. This patient came to see a wong pinter and ask that he pray for the patient's health. The patient was given 
prayer water, and after drinking this water felt that his stomachache was cured. When a mother had difficulty giving birth, a wong pinter was asked to pray for an easier birth. Someone having difficulty facing death could also ask a wong pinter for prayer to ensure they would be ready to die. Wong pinter often use plants and herbal mixtures to cure diseases and ailments. For instance, awar-awar leaves are used to prevent illnesses and dhadhap srep is used to treat fever. Burns, bites, and poisonings likewise all have their own specific treatments. Each wong pinter has his own "recipes".

Aside from treating physical illnesses, wong pinter are also often asked to help cure people who are thought to have been possessed by spirits. Such possession is believed to cause young children to become fussy or different to control. The wong pinter are also said to be able to treat black magic such as santet.

Wong pinter are also believed to be able to exorcise spirits from new homes, seek missing persons (especially children) who are thought to have been kidnapped by spirits, and ensure the safe return of someone who has journeyed afar. One source stated that he had asked a wong pinter who was also well versed in religious matters (a kyai) to pray that he find his missing wallet and his brother's missing wallet (two occasions). This kyai invited the informant to join mujahadah (group prayers) with his students, and both wallets were found.

For the Javanese, selecting the date on which something is done has an important role in determining that activity's future. One of the more famous Javanese almanacs is the Betaljemur Adammakna, which serves as a reference for the Javanese people's lives. This almanac includes methods for calculating appropriate or blessed dates for conducting certain activities. Wong pinter frequently understand such issues and are able to determine dates, and as such, members of the general populace (who lack such knowledge) will consult with them. This Javanese principle holds that there are good dates for conducting specific activities or holding certain ceremonies, and that these dates will ensure the greatest and most desired results.

Even today, the Javanese people often consult with the wong pinter regarding dates for weddings, circumcisions, and other life milestones. People also consult the wong pinter regarding the best dates for building homes or bridges or even for planting rice. All of this is intended to ensure that they benefit most from their activities or ceremonies. One tobacco merchant interviewed stated that he consulted with the wong pinter regarding the best dates to buy tobacco.

Life's many challenges cause people to face a large number and variety of problems. In general, patients need support, affirmation, and advice regarding the problems they face. Some of these problems are mental, while others have to do with the future. For instance, someone who will write a test, be it for school, employment, or promotion, will feel stressed and unconfident. In such conditions, patients often come to ask for prayers so that they can be psychologically prepared to write their tests. Persons disappointed over their inability to find a spouse can likewise consult a wong pinter and ask for prayers so that they may marry quickly. Wong pinter function to provide prayers and advice to their patients, and thus ensure peaceful living. In the words of one respondent, the wong pinter can help with thinking. They often provide motivation and remind patients of the importance of introspection. Wong pinter also provide advice regarding the importance of recognizing the fate determined by God and recommend that patients become more charitable and dedicated to prayer. Some entrepreneurs come to wong pinter to ask for prayers in support of their businesses.

\section{Motivation}

The motivation of the wong pinter for giving aid to others is based mostly in their desire to sincerely help their fellows. The motivations of the wong pinter in giving aid can be summarized as follows (Sartini \& Supartiningsih, 2016, pp. 33-34).

a. Love and care (welas asih). All creatures should care for each other, help each other, assist each other, particularly when they are facing unfortunate conditions.

b. Helping or assisting one's fellows by reducing the burdens of people who are suffering. Aiding others is considered a duty of all people. 
c. Desire to be useful to one's fellows and provide charity.

d. Helping sincerely for Allah, without hope of recompense.

e. Asking for God's help. If it is the fate of the sick person, then he or she will be cured.

f. Belief that, if one helps one's fellows, the persons helped will pray for the persons who helped them.

Some of the wong pinters provide healing and other social services because they hear the whispering of spirits, follow the instruction of their teachers, or unconsciously obtain healing abilities. Because of these abilities, they are sought by persons in need of aid. When practitioners are able to provide healing and other forms of aid, the emphasis is on their sincerity, on their willingness to give aid without asking for anything in return. Though they do not offer their services, they also do not refuse the requests of persons seeking them.

Another reason why the wong pinter continue their activities is because they have the support of their families and communities. They are considered important and necessary figures in their communities, as they have the ability to give advice and to heal. Many practitioners are respected and honored for their kindness.

\section{Social view}

Social reception of the wong pinter tends to be positive. The wong pinter are considered exemplary members of the community. They are thought trustworthy, able to tell good from bad, and unwilling to do wrong. If they do wrong, it is not deliberate. Such morality is attributed to them because the wong pinter are believed to be of strong faith, to be serious students of religion, and to approach themselves to God. In a Javanese context, they are persons with prihatin for Godi.e. their actions and methods are intended to bring them closer to God through certain religious or spiritual understandings. The wong pinter are no different than other members of the community. They do not isolate themselves or consider others to be beneath them. They intermingle with their communities, can easily socialize, are open, and are known to follow rules, diligently participate in social aid, and work hard. Wong pinter are considered exemplary citizens because they do everything well and give their best: their families are orderly and their children become members of the community. Wong pinter are considered humble and friendly, and owing to their statuses as exemplary citizens are often asked to give advice or direction to the community. In one case, a wong pinter named Mbah Mudah was given a special position within district-level discussions. Lower administrative levels (villages and hamlets) likewise often consult wong pinter for advice. Their wise views, simple comportment, humble and refreshing way of speaking, and their capacity as residents are all reasons for the wong pinter to be consulted for advice (Sartini, 2015, p. 33).

Although most are not formal leaders with the authority to make decisions, wong pinter are held as pillars of their communities because they value morality, serve as positive examples, and influence society with their advice. Wong pinter tend not to emphasize their own abilities. Wong pinter contribute to community decisions by providing advice regarding the best decisions to be taken (Sartini, 2015, p. 59).

Research conducted in 2014 (Sartini, 2014) and research conducted in 2016 (Sartini \& Supartiningsih, 2016) has shown that, generally, the wong pinter are received positively by their communities. They are needed to heal physical ailments and non-physical ailments, as well as to solve social problems and offer examples and advice. Nevertheless, owing to the variety of views held by members of their communities, there are still those who oppose the wong pinter.

Data indicates that such opposition often comes from groups categorized as being hardline Muslims who strictly promote the concept of Islamic purity. One source, Akhmad Daroji of Bejen, described these opponents as "Extremist Muslims". This minor segment of society opposes Akhmad Daroji and the other wong pinter and considers them to be misleading society, arguing that the healing provided by the wong pinter such as Ahmad Daroji goes against correct religious doctrine (as these groups understand it). Among his neighbors, however, Ahmad Daroji is known to be a devout Muslim who diligently goes to the mosque to pray, helps those who require assistance by providing them with prayer and 
herbal remedies, cures spiritual possession, and protects people being disturbed by evil spirits or afflicted by black magic. His service is provided freely, without any expectation of remuneration. Indeed, Ahmad Daroji prefers that his patients not give him any payment. Some of treatments provided involve prayer, including recitation of Al-Fatikhah and other short Qur'anic verses. Ahmad Daroji also mediates, seeking revelation in silent, isolated places. He explains that, sometimes, his spiritual experiences sometimes come from premonitions which are received through dreams. $\mathrm{He}$ thinks that it is his use of meditation which is considered to be against Islamic doctrine by these "extremist Muslims".

Likewise, Ahmad Daroji is occasionally suspected to be a dukun (in the negative connotation), even though he asks God the Almighty for help and prays to Him. The informant considers the Muslims who hold such views to be keminter (to consider themselves the most intelligent and correct). Despite facing such opposition, Akhmad Daroji continues to take positive courses of action, following the motto "ngalah, plalah, supaya ora kalah" (let it go, so you don't lose). He believes that all people should respond to negative actions with positive ones, and that giving in is not the same as losing. The informant believes that all of a person's negative actions will be repaid unto him or her in the future.

Another source, Mbah Gudik from Langgeng, Tlogomulyo, has had experiences which differ somewhat from those of Ahmad Daroji. Mbah Gudik is capable of communicating with the supernatural, but this cannot easily be learned or understood by others. No schools teach such abilities, Mbah Gudik says, and he does not know where his own abilities come from. All experiences which cannot easily, if at all, be explained or imagined by others will have those who refuse to belief them. Mbah Gudik explains that he is sometimes even considered to be "strange" (Sartini, 2015, p. 32).

Although these wong pinters did not have direct confrontations with persons holding extremist views, some sources explained that certain people did not believe in their abilities. Nevertheless, they have continued to maintain good relations with their communities.

\section{Use of modern technology}

Use of modern technology among the wong pinter tends to be minimal, as their becoming healers and helpers tends not to be a professional calling. Their actions are instead mainly intended to provide assistance when it is needed. If someone believes in their powers and comes to the wong pinter to ask for assistance, then they will help to the best of their abilities. There are no specific efforts to improve their abilities except for prayer and prihatin. People seeking aid are mostly influenced by their faith and their belief in specific healers' abilities.

In Java, there are the concepts of $\operatorname{cocog}$, of a patient matching his or her healer(Geertz, 1976, p. 91), and mandi, the success of a treatment. Patients may be treated more easily by specific healers. The term mandi is often related to phrases considered to have potent healing abilities (Sartini, 2014, p. 647).

The wong pinter's knowledge can be received from their parents, teachers, religious lessons, books, or other sources. Mostly, however, they are self-taught. They develop their abilities in accordance with the assistance expected by members of the community. According to Pak Darman, "Wong pinter kuwi duwe penemu dhewe" ("The Wong Pinter develop their abilities on their own"). This means that the wong pinter will independently find a way to treat patients and develop their own abilities, including in the areas of determining treatment regimens and resolving problems. Although such self-development tends not to use modern technology, continued social developments, including increased knowledge of religion, means that the wong pinter must regularly update their healing and service models (Sartini, 2014, p. 647).

\section{Relationship with religion}

With the increased development of religion and religious activities within their communities, the knowledge and religious devotion of the wong pinter has generally increased. This can be seen, for instance, in the adaptation of prayer to more closely follow readings of the Qur'an. Many prayers can be found in mantra form.

Mbah Cokro, for instance, provided services through several forms of fasting, namely: mutih 
(only consuming plain rice and water), ngebleng (one-day fast), ngadhem (not consuming any spices), and pati geni (full fasting, with one being confined to a limited space). Mbah Cokro continued to help patients until his death in 1963. At the time, few people prayed strictly in accordance with Islamic doctrine; they generally relied on slametan or kenduren, a prayer ritual which involved eating together. At the time, mantras and healing prayers involved a mixture of the Javanese and Arabic languages. For instance, the opening prayer which is properly pronounced Bismillahirohmanirohim in Arabic was simply pronounced Semillah (Sartini, 2014, p. 645).

The handling of different cases relies on different prayers or mantras. When someone is to be called home, the Donga Pemeling is used to communicate with the spirit/non-human world to ask for that person's safe return. Cases of missing people, or people who are thought to have been hidden by evil spirits, are handled by reciting the Srabat Putih mantra and reading several verses of the Qur'an (Sartini, 2014, p. 646).

According to another source, treatments may involve the recitation of sholawat, Qur'anic verses, or even joint prayer (mujahadah). This occurs because many of the informants in Temanggung have a pesantren (Islamic boarding school) education, including Arisun, Rohim, Ismanto, Ahmad Nasikhun, Abdul Fatah (Sartini \& Supartiningsih, 2016), Ustadz Isro'i Suyuti, and Ustadz M. Nur Amin (Sartini, 2015, p. 33).

Generally, the wong pinter closely follow their religious duties. They are considered faithful people who pray regularly and consider their powers to have come from God. The actions of the wong pinter are stated by the informants to be based in religious syari'at (law). The wong pinter help their patients recognize the importance of surrendering themselves to God. Their advice generally complies with, rather than deviates from, religious teachings (Sartini, 2014, p. 29).

\section{Wise to Use the Term}

There are several reasons why it needs comprehensive understanding in view of the phenomenon and wise in using the term.

1. The Background of the history and Javanese Culture
Less developed societies tend to rely on the services of dukun. The fertile growth of traditional medicine in Indonesia has also been influenced by the country's conditions. The history of health, disease, and healthcare before Indonesia proclaimed its independence has remained understudied, and as such information on it remains scarce (Boomgaard, 1993, p. 77). Healthcare in Java in the early $20^{\text {th }}$ century was provided by practitioners known as dokter Jawa (Javanese doctors) and dukun. At the time, medical journals answered questions regarding health and its connection to superstition (Monnais \& Cook, 2012a, p. 108) and to supernatural beliefs, as well as the use of chewed areca nuts for treating of eczema (Monnais \& Cook, 2012b, pp. 109-110).

Kurniarini, Darini, \& Dewi (2015, p. 12) depicts late Dutch East Indies as being a society in which healthcare quality was improving, but only among certain parts of society. Though the indigenous population of Java did receive some education in healthcare issues such as hygiene and sanitation, as well as smallpox vaccinations, these facilities were unable to reach all of society. The populace tended to rely on traditional treatment regimens rather than modern medicine. Indeed, from the time of the Dutch East India Company until the $20^{\text {th }}$ century, the Dutch colonial government deliberately allowed the indigenous population to use the services of the dukun and tabib for their healthcare needs (Baha'uddin, n.d., p. 1).

Parts of Javanese society still practice a personalistic etiology (explanation for the origin of disease), and thus make use of traditional healing practices. Societies whose etiology is mainly personalistic tend to seek treatment from local practitioners, who are known as shamans (or, in Indonesia, dukun) and are considered capable of both directly communicating with the spirit world and of using magic (Foster \& Anderson, 2006, pp. 82-83). Traditional healing here can be understood as healing or treatment using techniques which have been continuously practiced in society for hundreds of years, before the advent of modern medicine. Traditional healing systems are part of the traditional knowledge system and the technological aspects of Javanese culture (Sudardi, 2002, p. 12). This situation forced members of society, particularly women, to form their own 
health management systems (Hull, 1979) despite limited resources and facilities (Hull, 1981).

According to Santino, traditional healing (also known as folk medicine) gains its effectiveness from being a manifestation of faith, symbols, and customary actions, as well as social behavior. In such medicine, faith is utilized for practical purposes and has direct consequences on health and treatment. Activities are both spiritual and pragmatic, sacral and secular (Santino, 1985, p. 153). This can be seen from the fact that faith and medical treatments are among the oldest objects of study in medical anthropology. Faith-related medicine is, together with its practice, a central part of culture (Foster \& Anderson, 2006, p. 61). Every social group has its own basic medical knowledge.

Even today, at the beginning of the $21^{\text {st }}$ century, traditional healers and treatment in Java have remained similar to those discussed above. This is shown by, among others, research conducted by Daniels and Woodward. One profile provided by Daniels indicates that traditional healing practices still involve efforts to strengthen one's inner powers through prayer recitation, fasting, and meditation. Although communication with God, realized through prayer, is prioritized, it is supported through communication with the other beings created by Him, including the jinn, demons, and other spirits. These practices are syncretic in character, combining Javanese mysticism with Islam (Daniels, 2009a, p. 61).

\section{The process of forming a world view}

View of the world is a unique initiative of individuals or groups. World view with regard to the philosophy of life, a way of thinking, life expectancy, the principle of life, ideology, faith or even religion (Abdullah \& Nadvi, 2011, p. 270). It was a system of organized knowledge culturally (Kearney, 1975, p. 248), whereas for Carvalho (2006, p. 113), a world view is a belief system that is associated with the nature of reality and how one acts as a subject in the reality. As a process of cultural and social phenomenon that is constantly moving and always changing, there is constant interaction so the perception of the world view of a society or any individual basically have a temporal dimension (Abdullah \& Nadvi, 2011, p. 270). Nevertheless, changing worldview of a person or group of people is not easy.

It takes time to change the world view of an individual or a community. It is highly recognized by people engaged in religious conversion, as seen in the analysis of Hiebert (Hiebert, 2002, pp. 7-11) on conversion or religion of transformation. There are three levels in the conversion process, namely: behavior and rituals, beliefs, and worldview. Hiebert pointed out that if there is a Hindu to Christianity in a short time actually means that happened was a change at the level of syncretic behavior. The level of belief and world view of the person or group is not easily changed because someone lives in the context of the long-running human who has formed his thinking. Changes in world view can not be an instantaneous process and changes occur slowly, even coercive transfer of world views can lead to conflict. Java community experience shows that transformation.

It occurred "religious compromising" in Java because some people nominally converted to Islam but they still follow the religious understanding that has long roots. They still do old rites (Masroer Ch. Jb., 2004, p. 31). Islam developed to the community who are influenced by Hindu and strong local understandings. Therefore, the Sufis who preach Islam accommodate local beliefs in order to make up the Javanese Islamic rituals, as offered by a group of Islamic preachers, known as Wali Sanga. The teachings of Islam coexist with different belief to keep peace and tolerance (Ridwan, 2008, p. 1.4). The use of mysticism approach leads the process of religious conversion growing more tolerant, adaptive, and open to a lot of views. It is considered as the ideal medium to bring together religion and belief there (Ridwan, 2008, p. 13). This compromise approach is also visible in the pesantren (Islamic boarding). Pesantren Tegalrejo Magelang obligates the students the tasawuf as one of objects of study (Pranowo, 2011, p. 192) and it shows the life of the students who run the Sufi rites. They do fasting mutih (eat only rice or tubers and water), ngrowot (eat only tubers) (Pranowo, 2011, p. 2014)"edition":"2","eventplace":"Jakarta","ISBN":"978-979-3064-703","language":'Indonesia","author":[\{“family":" Pranowo","given":"Bambang"\}],"'issued": \{“dateparts":[[“2011"]]\}\},"locator":"2014"\}],"schem a":"https://github.com/citation-style-language/ 
schema/raw/master/csl-citation.json"\} . Most activities have similarities to the rituals of selfcontrol in the Java community (Koentjaraningrat, 1994, p. 371). Conversion of belief and religion needs wisdom and process. A confrontational approach to convert people may lead to certain conflicts in society.

\section{What should we do?}

The use of the term "dukun" and "wong pinter" should be used appropriately because both these designations do not designate characteristics of the same profile. Both terms need specific definitions The use of appropriate terms will make social relationships become more harmonious. It is expected there will be no claims, prejudices, and destructive actions to accommodate the difference. It is required multicultural awareness and not to impose views on others.

If there is an effort to influence the views of other members of society, then it should be done subtly and wisely. Coercion changes in world view cannot be done because of a change in the primary level could lead to conflict in society, such as the imposition of a ritual execution.

\section{CONCLUSION}

Researches on Javanese traditional healers have been a tendency to equate the notion dukun, wong pinter and other practitioners in particular of "magico-specialist" practitioners. Yet found a reference that specifically point out differences among these practitioners, specifically "dukun" and "wong pinter". In fact, there are significant differences between them. Therefore, whoever needs to wisely use the terms because it was in these terms are contradictory predicates, negative and positive connotations. In needs specific definitions among the terms. Mentioning one for all terms can invite discomfort or even false claims and actions. Attempts to do the transformation or conversion of beliefs and worldviews are not an easy thing to do. As a worldview, understanding a person or group is accumulated understanding of history which is formed in a long time. Thoughtful actions and appropriate use of the term is necessary to not generalize what the term means.

This paper contributes to providing more information that is the difference between practitioners and further understanding of the public about these differences so the public and scientists in particular can use that term proportionally.

\section{REFERENCES}

Ali, Z. (1995). Note on a Pair of Batu Aceh in Rembau. Journal of the Malaysian Branch of the Royal Asiatic Society, 68(1 (269)), 81-89.

Atkinson, J. M. (1992). Shamanisms Today. Annual Review of Anthropology, 21(1), 307-330. https://doi.org/10.1146/annurev. an.21.100192.001515.

Baha'uddin. (n.d.). Dokter Jawa dan Mantri Kesehatan dalam Sejarah Kesehatan Indonesia pada Masa Kolonial https///www.academia.edu/4435361/ dokter_Jawa_dan_Mantri_Kesehatan.

Bandel, K. (2006). Sastra, Perempuan, Seks. Yogyakarta: Jalasutra.

Bernstein, J. H. (1993). Poisons and Antidotes Among the Taman of West Kalimantan Indonesia. Bijdragen Tot de Taal, Land-En Volkenkunde, 149(1), 3-21.

Boomgaard, P. (1993). The Development of Colonial Health Care in Java; An Exploratory Introduction. Bijdragen Tot de Taal, Land-En Volkenkunde, Deel 149(ieste Afi), 77-93.

Bubandt, Ni (2006). Sorcery, Corruption, and the Dangers of Democracy in Indonesia. The Journal of the Royal Anthropological Institute, 12(2), 413-431.

Caniago, I., \& Siebert. (1998). Medicinal Plant Ecology, Knowledge and Conservation in Kalimantan, Indonesia. Economic Botany, 52(3), 229-250.

Chilson, C., \& Knecht, P. (2003). Shamans in Asia. London; New York: RoutledgeCurzon.

Connor, L. H. (1990). Seances and Spirits of teh Death: Context and Idiom in Symbolic Healing. Oceania, 60(4), 345-359.

Daniels, T. P. (2009a). Islamic spectrum in Java. Farnham, England; Burlington, VT: Ashgate. Retrieved from http://public.eblib.com/ EBLPublic/PublicView.do?ptiID=449235.

Daniels, T. P. (2009b). Islamic spectrum in Java. Farnham, England; Burlington, VT: Ashgate. Retrieved from http://public.eblib.com/ EBLPublic/PublicView.do?ptiID=449235

Edson, G. (2012). Mysticism and alchemy through the 
ages the quest for transformation. Jefferson, N.C.: McFarland \& Company. Retrieved from http://search.ebscohost.com/login.aspx?direct $=$ true \& s c ope $=$ site $\& d b=n l e b k \& d b=$ nlabk\&AN=480922.

Eliade, M. (1989). Shamanism: archaic techniques of ecstasy. London, England: Arkana.

Faucher, C. (2002). Magical Discourse, Moral Boundaries, and the Mapping of Interrelations in the Riau Archipelago. Asian Journal of Social Science, 30(1), 158-176.

Foley, K. (1984). Of Dalang and Dukun-Spirits and Men: Curing and Performance in the Wayang of West Java. Asian Theatre Journal, 1(1), 52. https://doi.org/10.2307/1124366.

Foster, G. M., \& Anderson, B. G. (2006). Antropologi Kesehatan. Judul Asli: Medical Anthropology. Jakarta: Penerbit Universitas Indonesia.

Gaines, P. (2002). Correspondence from Abroad: A Visit with the Revered Dukuns in Indonesia. The American Journal of Nursing, 102(1), $69,71,72,75$.

Geertz, C. (1976). The religion of Java. Chicago: University of Chicago Press.

Grim, J. (1987). The shaman: patterns of religious healing among the Ojibway Indians. Norman, Okla.: University of Oklahoma Press.

Harvey, G., Wallis, R. J., \& Harvey, G. (2010). The A to $Z$ of shamanism. Lanham, Md.: Scarecrow Press.

Heggemhougen, H. K. (n.d.). Traditional Medicine and the Treatment of Drug Addicts: Three Ezamples from Southeast Asia. Medical Anthropology Quarterly, 18(1), 3-7.

Heinze, R.-I., \& Berney, C. (1991). Shamans of the 20th century. New York: Irvington.

Herriman, N. (2006). Fear and Uncertainty: Local Perception of teh Sorcerer and the State in an Indonesian Witch-hunt. Asian Journal of Social Science, 34(3), 360-387.

Herriman, N. (2010). The Great Rumour Mill: Gossip, Mass Media, and the Ninja Fear. The Journal of Asian Studies, 69(3), 723-748.

Hesselink, L. (2011). Healer in the Colonial Market: Native Doctorand Midwives in the Dutch East Indias. Leiden: KITLV Press.

Horikoshi-Roe, H. (1979). Mental Illness as a Cultural Phenomenon: Public Tolerance and Therapeutic Process among the Moslem Sundanese in West Java. Indonesia, 28, 121. https://doi.org/10.2307/3350898.

Hull, V. J. (1979). Women, Doctors, and Family Health Care: Some Lessons from Rural Java. Studies in Family Planning, 10(11/12), 313. https:// doi.org/10.2307/1966086.

Hull, V. J. (1981). The Right to Health Care: Building on Traditional Self-Reliance in Village Java. Human Rights Quarterly, 3(2), 61. https://doi. org/10.2307/761858.

Indrasuari, A. F. (2012). Kepercayaan Pedagang terhadap Wong Pinter dalam Menunjung Usaha Dagang di Pasar Bintoro Demak. Jurnal SolidarityUniversitasNegeriSemarang,I(1).

Jordan, K. (n.d.). Shamanism in Pre-Columbian Mesoamerica. In H. Selin (Ed.), Encyclopaedia of the History of Science, Technology, and Medicine in Non-Western Cultures (pp. 19992002). Dordrecht: Springer Netherlands. Retrieved from http://www.springerlink.com/ index/10.1007/ 978-1-4020-4425-0_9770

Khiun, L. K. (2012). Liberalism, Feminism, Popularizing Health Communication. England: Ashgate Pub. Ltd.

Koentjaraningrat. (1994). Kebudayaan Jawa. Jakarta: Balai Pustaka.

Kurniarini, D. D., Darini, R., \& Dewi, I. M. (2015). Pelayanan dan Sarana Kesehatan di Jawa Abad XX. Mozaik, (7), 1-15.

Landy, D. (1974). Role Adaptation: Traditional Curers uner the Impact of Western Medicine. American Ethnologist, 1(1), 103-127.

Lebra, W. P. (1985). Shamanism in a Contemporary Medical System: The Okinawan Case. In P. Pichot, P. Berner, R. Wolf, \& K. Thau (Eds.), Psychiatry The State of the Art (pp. 659-665). Boston, MA: Springer US. Retrieved from http://link.springer.com/10.1007/978-1-47571853-9_105

Lemelson, R. B. (2004). Traditional Healing and Its Discontents: Efficacy and Traditional Therapies of Neuropsychiatric Disorders in Bali. Medical Anthropology Quarterly, 18(1), 48-76.

Maddox, J. L. (2003). Shamans and shamanism. Mineola, NY: Dover Publications.

Matondang, S. T. (2014). Nilai-nilai Simbolik upacara adat Belian Masyarakat Dayak Paser Kalimantan Timur. Skripsi Fakultas Filsafat UGM.

Monnais, L., \& Cook, H. J. (2012a). Global Movements, 
Local Concerns: Medicine and Health in Southeast Asia. Singapore: NUS Press Pte Ltd.

Monnais, L., \& Cook, H. J. (2012b). Global Movements, Local Concerns: Medicine and Health in Southeast Asia. Singapore: NUS Press Pte Ltd.

Mulder, N. (2005a). Mysticism in Java: ideology in Indonesia (2nd ed). Deresan, Yogyakarta, Indonesia: Kanisius Pub. House.

Mulder, N. (2005b). Mysticism in Java: ideology in Indonesia (2nd ed). Deresan, Yogyakarta, Indonesia: Kanisius Pub. House.

Olthof, W. L. (2014). Babad Tanah Jawi (Hard Cover). Yogyakarta: Narasi.

Pearson, J. L. (2002). Shamanism and the ancient mind: a cognitive approach to archaeology. Walnut Creek, CA: AltaMira Press.

Peletz, M. G. (1988). Poisoning, Sorcery, and Healing Rituals in Negeri Sembilan. Bijdragen Tot de Taal, Land-En Volkenkunde, Deel 144(1ste Afi), 132-164.

Pranowo, B. (2011). Memahami Islam Jawa (2nd ed.). Jakarta: Pustaka Alvabet.

Retsikas, K. (2002). The Sorcery of Gender: Sex, Death and Difference in East Java, Indonesia. South East Asia Research, 18(3), 471-602.

Santino, J. (1985). On The Nature of Healing as a Folk Event. Western Folklore, 44(3), 153. https:// doi.org/10.2307/1499833.

Sartini. (2014). Profil Wong Pinter Menurut Masyarakat Temanggung Jawa Tengah. Laporan Penelitian Fakultas Filsafat UGM Yogyakarta.

Sartini. (2014). Wong Pinter di Antara Para Penyembuh Tradisional Jawa. Patrawidya, 15(4), 641-664.

Sartini. (2014). Wong Pinter di Antara Para Penyembuh Tradisional Jawa. Patrawidya, 15(4), 641-664.

Sartini. (2015). Pengalaman Mistik Wong Pinter di Temanggung Jawa Tengah. Laporan Penelitian Fakultas Filsafat UGM Yogyakarta.

Sartini. (2015). Profil Wong Pinter Menurut Masyarakat Temanggung Jawa Tengah. Patrawidya, 16(2), 269-286.

Sartini. (2015). Wong Pinter sebagai Model Keteladanan Kepemimpinan Jawa. Jantra, 10(1), 59-70.

Sartini, \& Supartiningsih. (2016). Penyembuhan Tradisional Jawa Studi Kasus pada Praktik Wong Pinter di Temanggung Jawa Tengah. draft Laporan Penelitian Kemenristekdikti.
Schlehe, J., Nertz, M. V., \& Yulianto, V. I. (2013). Re-imagining "the West" and performing "Indonesian Modernities": Muslims, Christian and "Paranormal" Practitioners. Zeitsschrift Fur Etnologie, 138(1), 3-21.

Siegel, J. T. (2001). Suharto, Witches. Indonesia, 71, 27. https://doi.org/10.2307/3351456

Singarimbun, M., \& Manning, C. (1974). Marriage and Divorce in Mojolama. Indonesia, 17, 67. https://doi.org/10.2307/3350773.

Sofwan, R. (2010). Peranan Wong Pinter dalam Pengobatan Alternatif Di Kota Semarang. Lemlit IAIN Walisongo Semarang.

Suanda, E. (1981). The Social Context of Cirebonese Performing Artists. Asian Music, 13(1), 27. https://doi.org/10.2307/834084.

Sudardi, B. (2002). Konsep Pengobatan Tradisional Menurut Primbon Jawa. Umaniora, 14(1), 12-19.

Sutiono, A. (2014, April). The Role of Significance of Wong Pinter, The Javanese Shaman. The University of Leeds York St. John University.

Taussig, M. (1987). Shamanism. Colonialism, and the Wild Man: A Study in Teror and Healing. Chicago and Lodon: The University of Chicago Press.

Trisakti, S. B. (2009). Kecerdasan Lokal dalam Prosesi Ritual Menjadi Balin pada Masyarakat Dayak. Laporan Penelitian Fakultas Filsafat UGM Yogyakarta.

Viner, A. C., \& Kaplan, E. L. (1981). The Changing Pakpak Batak. Journal of the Malaysian Branch of the Royal Asiatic Society, 54(1 (239)), 93-105.

Wessing, R. (1996). Rumours of Sorcery at an Indonesian University. Journal of Southeast Asian Studies, 27(2), 261-279.

Wiener, M. J. (2007). Dangerous Liaisons and Other Tales from the Twilight Zone: Sex, Race, and Sorcery in Colonial Java. Comparative Studies in Society and History, 49(3), 495-526.

Winkelman, M. (2010). Shamanism: a biopsychosocial paradigm of consciousness and healing (2nd ed). Santa Barbara, Calif: Praeger.

Woodward, M. (2011). Java, Indonesia and Islam (1st ed). Dordrecht; New York: Springer. 